\title{
Самовосстановление степных экосистем на постцелинном пространстве в свете концепции титульных видов степей, его экосистемного и природоохранного значения
}

\section{Steppe ecosystem self-restoration on the virgin land campaign area in the light of the steppe title species concept, environmental and conservative significance of the process}

\author{
Левыкин С. В., Казачков Г. В., Яковлев И. Г., Грудинин Д. А. \\ Levykin S. V., Kazachkov G. V., Yakovlev I. G., Grudinin D. A. \\ Институт степи УрО РАН, г. Оренбург, Россия. E-mail: stepevedy@yandex.ru \\ Institute of Steppe of the Urals Branch of RAS, Orenburg, Russia
}

Peфepam. На основе результатов многолетних полевых обследований постцелинного пространства в его западном секторе и на стыке центрального и восточного секторов изучена специфика процессов самовосстановления титульных степных видов, показывающая их особую экосистемную и природоохранную ценность.

Ключевые слова. Вторичная степь, ковыль Лессинга, ковыль красный, постцелинное пространство, самовосстановление степей.

Summary. The specificity of steppe title species self-restoration processes, showing their exceptional environmental and conservative worth, is studied through many year field observations of the virgin land campaign area in its western sector and in the joint of its central and eastern sectors.

Key words. Secondary steppe, Stipa lessingiana Trin. et Rupr., Stipa zalesskii Wilensky, steppe self-restoration, virgin land campaign area.

Из всех природных зон Северной Евразии именно степная стала основной зоной товарного зернового производства. По этой причине она была распахана с особой тщательностью, исторический минимум степей и максимум посевных площадей пришёлся на 1990 г. Затем по общеизвестным причинам сложились условия самовосстановления степей, исторический максимум которых зафиксирован нами в 2012-2014 гг. Затем площади залежей стали быстро сокращаться под действием рыночной конъюнктуры и административных требований. По нашим оценкам, к 2025 г. посевные площади, возможно, превысят позднесоветский максимум за счёт продовольственной пшеницы и подсолнечника. В этой связи особую актуальность приобретают сведения о специфике самовосстановления степных фитоценозов в период последней пахотной передышки.

Соответственно динамике степного землепользования последних десятилетий и сохраняющейся остроте проблемы выживания степей прослеживается адекватное развитие подходов к сохранению степей. Для конца 1980-х характерен экстренный подход, направленный на оперативное сохранение любых уцелевших остатков степей в рамках ООПТ. В 1990-е гг. уже принципиальным образом ставится вопрос о сохранении и восстановлении степных массивов на плакорах, в т. ч. на землях Министерства Обороны РФ. С 2000 г. закладываются теоретические основы степного ревайлдинга - новационного направления по восстановлению полночленности путём реинтродукции степных копытных: лошади Пржевальского, равнинного бизона и др. В настоящее время на основе изучения постцелинного пространства, прежде всего его Заволжско-Тургайского сектора, разрабатывается концепция сохранения степей с элементами управления их вторичными фитоценозами, поддерживающими их в наивысшей биологической и генеративной продуктивности. 
В 2019 г. исполняется 65 лет началу массового освоения целинных и залежных земель и 25 лет всестороннему обсуждению этого мегапроекта. На всех уровнях в очередной раз будет поднята проблема «пустующих земель». Нами с позиций степеведения проведена системная оценка основных уроков и последствий целины, по итогам которой мы пришли к пониманию выдающейся роли этого мегапроекта по глобальному омолаживанию, своего рода «перезагрузке» степных фитоценозов, результаты которого и наблюдаются на протяжении последних десятилетий (Левыкин и др., 2015).

В качестве постцелинного пространства нами рассматривалась подзона сухих степей от Заволжья до предгорий Алтая с низким зернопроизводственным потенциалом, наиболее ярко выраженной динамикой структуры агроландшатфов, уместностью природных и полуприродных травяных экосистем и возможностями их интеграции в систему землепользования (Левыкин, Казачков, 2017б; Левыкин и др., 2018). С учётом существующего районирования и наших исследований это пространство нами было разделено на западный (Заволжско-Тургайский), центральный (Карагандинский), восточный (Павлодарско-Кулундинский) сектора.

На этапе 2008-2017 гг. был детально изучен западный сектор: широтная полоса протяжённостью 1300 км и шириной 100 км площадью 13,5 млн. га с центром в г. Оренбурге. Это в основном сухостепная подзона на каштановых почвах, где до целинной кампании 1950-х гг. плакоры, покрытые различными вариантами лессингоковыльных степей (Stipa lessingiana Trin. et Rupr.), занимали 7 млн. га. По мере эволюции наших подходов это пространство изучалось на предмет поиска сохранившихся степных плакоров, генеративного потенциала фитодоминантов и их реакции на пахотную передышку, динамики титульных видов степей и поиска возможностей управления ими. Результатом стала база данных основных участков целинных и вторичных степей, в т. ч. распаханных, и выявленные закономерности самовосстановления степей (разные по вторичным степям).

Приуроченность ковыля Лессинга (Stipa lessingiana Trin. et Rupr.) к суглинистым разновидностям полнопрофильных почв признанных зональными, его свойства пионерного растения, проявляющиеся в быстром формировании зарослей на залежах, наиболее активное заселение его зарослей титульными степными животными считаем основаниями рассматривать этот вид в качестве зонообразующего - одного из главных строителей экосистемного базиса степей. Поэтому признаём его заросли принципиальным шагом в самовосстановлении степной титульности и поэтому высоко ценными в экосистемном и природоохранном отношениях (Левыкин, Казачков, 2017a). Наши результаты в целом согласуются с наблюдениями немецких коллег, работавших в Северном Казахстане, однако ими ценность вторичных степей в большей степени воспринимается исходя из приоритета фиторазнообразия, обусловленного выпасом (Brinkert et al., 2016).

В 2018 г. начаты полевые обследования на стыке центрального и восточного секторов в окрестностях оз. Силети-Тенгиз, одного из крупнейших в Северном Казахстане. В результате полевых исследований выявлен ряд целинных и вторичных степных экосистем: участок вторичной лессингоковыльной степи (Stipa lessingiana) у пос. Мортык (стрепет, сурок), участок вторичной лессингоковыльной степи у пос. Коктерек (стрепет, сурок), участок целинной и вторичной типчаково-лессингоковыльной степи (Festuca valesiaca Gaudin, Stipa lessingiana) в выступе Павлодарской области, примыкающем с востока к оз. Силети-Тенгиз (стрепет, сурок), участок вторичной красноковыльной степи (Stipa zalesskii Wilensky) на легкосуглинистых чернозёмах в окр. пос. Силеты Павлодарской области, эталонные участки морковниково-типчаково-красноковыльных степей (Silaum silaus (L.) Schinz et Thell., Festuca valesiaca, Stipa zalesskii) и примыкающий участок вторичной лессингоковыльной степи (Stipa lessingiana) у пос. Золотая Нива, массивы вторичных разнотравно-красноковыльных (Stipa zalesskii) и красноковыльных (Stipa zalesskii) степей между сёлами Акбулак и Кишкенеколь.

В Жаскайратском, Кулыкольском и аналогичных выступах Северо-Казахстанской области отмечены густые заросли многолетних трав, костра (Bromopsis inermis (Leyss) Holub) и житняков (Agropyron $s p p$.) на тысячах гектаров, которые служат кормовой базой развития животноводства.

Во время экспедиции (начало июля) отмечены следующие факты: массовый аспект цветения ковыля Лессинга (Stipa lessingiana) в 2018 г. сместился на месяц позже, со слов местных жителей ковыль Лессинга на солонцеватых южных чернозёмах буквально за три года осваивает залежные земли даже после нескольких попыток проведения фитомелиорации многолетними травами. 
Детальное обследование западного сектора постцелинного пространства и первые исследования на стыке центрального и восточного секторов позволили сделать следующие выводы, заключения и предложения:

1. Подтверждены пионерные свойства, вплоть до проявлений агрессивного внедренца, у титульных степных биологических видов, прежде всего ковылей: Лессинга (Stipa lessingiana) на суглинистых разновидностях южных чернозёмов и каштановых почв, Иоанна (Stipa pennata L.) на супесчаных почвах и песках.

2. Доказана экологическая обратимость глобального целинного эксперимента в силу уникальной жизнестойкости титульных видов степей: экосистемный базис в виде степных зарослей восстанавливается за 10-15 лет.

3. Наиболее крупный целинный плакорный степной массив (800 га) на тёмно-каштановых почвах (областной памятник природы Джабыгинская степь) выделен нами в Оренбургском Зауралье.

4. Наиболее оптимальные условия самовосстановления, приводящие к формированию чистых зарослей ковыля Лессинга (Stipa lessingiana), выявлены в западной части западного сектора на южных отрогах Общего Сырта (Западно-Казахстанская область).

5. В центральной части западного сектора на Подуральском меловом плато заросль формируют ковыль Лессинга (Stipa lessingiana) и житняки (Agropyron spp.) в разных соотношениях.

6. После пожаров 2013-2014 гг. житняки (Agropyron spp.) практически полностью вытеснили ковыль (Stipa lessingiana) и выглядели как сплошные посевы.

7. В Зауралье и Тургае, где преобладает падинно-плакорный рельеф, наблюдается дифференциация восстановленной растительности. В падинах доминирует вострец (Leymus ramosus (Trin.) Tzvel.) (20-40 \% площади), между падинами - ковыль Лессинга (Stipa lessingiana). Неоднократные пожары показывают устойчивость этого распределения.

8. Ритмика массового цветения и плодоношения ковыля Лессинга (Stipa lessingiana) не полностью укладывается в четырёхгодичный цикл, а обусловлена, прежде всего, степенью осенней влагозарядки почвы и молодостью заросли.

9. Заросли ковыля Лессинга (Stipa lessingiana), в т. ч. в сочетании с другими видами растений, активно заселяются такими титульными степными животными как стрепет, сурок, дрофа, сайгак.

10. Целинные морковниково-красноковыльные степи (Silaum silaus (L.) Schinz et Thell., Stipa zalesskii) практически утрачены, нами на стыке центрального и восточного секторов выделены лишь фрагменты площадью от 0,3 до 1,5 га.

11. На крайнем юго-востоке Северо-Казахстанской области и северо-западе Павлодарской области ковыль Лессинга (Stipa lessingiana) продолжает проявлять свойства агрессивного внедренца, отмеченные в западном секторе, и активно осваивает залежные земли на тяжёлых суглинках, в т. ч. солонцеватых.

12. Как и в западном секторе, заросли ковыля Лессинга (Stipa lessingiana) проявляют себя как экосистемный базис, заселяющийся сурком и стрепетом.

13. На стыке центрального и восточного секторов ковыль красный (Stipa zalesskii) на южных чернозёмах сформировал чистые и смешанные заросли обильно заселяющиеся сурком и стрепетом.

14. Так как ковыль красный (Stipa zalesskii) является охраняемым видом, мы рекомендовали казахстанским коллегам на все выявленные участки его доминирования ввести мораторий на распашку, в т. ч. в качестве резервата сурка.

15. Массивы житняка (Agropyron spp.) и костра (Bromopsis inermis) на стыке центрального и восточного секторов, также в западном секторе, вероятнее всего, являются стадией пирогенных сукцессий.

В заключение можно отметить, что сохраняется тенденция массовой распашки вторичных степей в Заволжско-Тургайском секторе, но в Павлодарской области, прежде всего на границе с Алтайским краем, пока сохраняется крупнейший на постцелинном пространстве массив залежей и вторичных степей (Плуталова, 2018). Поэтому необходимо оперативное изучение восточного сектора постцелинного пространства объединёнными усилиями казахстанских и российских специалистов на предмет реальных масштабов экспансии титульных степных биологических видов, прежде всего ковыля 
красного (Stipa zalesskii). Развитие российского участия в комплексных обследованиях этой территории возможно в формате научной интеграции кафедры ботаники Алтайского государственного университета и Института степи УрО РАН, что позволит выйти на уровень современных концепций сохранения, восстановления степных экосистем и управления ими. При этом необходимо согласование подходов к оценке вторичных степей, прежде всего признания особой ценности не только за концентрированным фиторазноообразием, трактуемого немецкими коллегами, но и за монотонной зарослью фитодоминанта, выполняющей роль экосистемного базиса степей.

Работа выполнена по теме НИР ИС УрО РАН №ГР АААА-А17-117012610022-5.

\section{ЛИТЕРАТУРА}

Левыкин $\boldsymbol{C}$. В., Казачков Г. В. К обоснованию концепции титульных биологических объектов степей Северной Евразии // Биологическое разнообразие азиатских степей. Материалы III междунар. науч. конф. (24-27 апреля 2017 г., г. Костанай, Казахстан) / под науч. ред. Е. А. Абіль, Т. М. Брагиной. - Костанай: КГПИ, 2017а. - С.32-36.

Левыкин С. В., Казачков Г. В. Новая парадигма ковыльных степей постцелинного пространства: суть, управление, сосуществование // Охрана природы и региональное развитие: гармония и конфликты (к Году экологии в России): материалы междунар. науч.-практ. конф. и школы-семинара молодых ученых-степеведов «Геоэкологические проблемы степных регионов», (п. Партизанский Бузулукского р-на Оренбургской области, 01-05 октября 2017 г.). - Оренбург: Институт степи УрО РАН, 2017б. - Т. 1. - С. $23-26$.

Левыкин С. В., Казачков Г. В., Нурушев М. Ж. Ландшафтная матрица ковыльных степей постцелинного пространства // Степи Северной Евразии: материалы VIII международного симпозиума /под науч. ред. акад. РАН А. А. Чибилёва. - Оренбург: ИС УрО РАН, 2018. - С. 561-564.

Левыкин С. В., Казачков Г. В., Чибилёва В. П. Современная парадигма целины: распашка новых степей или агровозрождение Нечерноземья? Биосферная значимость и перспективы // Проблемы региональной экологии, 2015. - №3. - C. 228-233.

Плуталова Т. Г. Геоэкологическая оценка состояния и развития системы землепользования в условиях трансграничности (на примере трансграничной территории «Кулунда»): Автореф. ... канд. геогр. наук. - Барнаул, 2018. $-20 \mathrm{c}$.

Brinkert A., Hölzel N., Sidoriva T. V., Kamp J. Spontaneous steppe restoration on abandoned cropland in Kazakhstan: grazing affects successional pathways // Biodiversity and Conservation, 2016. - Vol. 25, iss. 12. - P. 2543-2561. 